\title{
Exporting Democracy and Liberating Women: An Examination of a Debilitating Rhetoric
}

\author{
Mais Qutami ${ }^{1} \&$ Suha Qutami ${ }^{2}$ \\ ${ }^{1}$ Assistant Professor, English Language and Literature Department, Al Zahra College for Women, Oman \\ ${ }^{2}$ Assistant Professor of English Literature, Department of Instructional Services, Toronto District School Board. \\ Toronto, ON, Canada \\ Correspondence: Mais Qutami, English Language and Literature Department, Al Zahra College for Women, \\ Oman. E-mail: eternalmais@yahoo.com
}

Received: January 6, 2013 Accepted: February 7, 2013 Online Published: February 22, 2013

doi:10.5539/ells.v3n1p122 URL: http://dx.doi.org/10.5539/ells.v3n1p122

\begin{abstract}
Democracy and freedom are valuable principles and main constituents of the American "way of life" which many countries aspire to. This may be true, but when such a freeing democracy is exported in a standardized western style and imposed on other nations, it becomes oppressive, debilitating, and uninspiring. This paper examines the double standards used in relation to issues of democracy and veiling within US rhetoric and hegemonic discourses. It also highlights what US democracy means to nations like Afghanistan, Egypt, and Iraq. It aims to underline the impact of the rhetoric of freedom and democracy on the Muslim world. This argument has important implications for theory and practice directed at disturbing dominant discourses of democracy and veiling.
\end{abstract}

Keywords: hegemony, discourse, democracy, veiling, Muslim women, rhetoric

\section{Introduction}

"All who live in tyranny and hopelessness can know: the United States will not ignore your oppression, or excuse your oppressors. When you stand for your liberty, we will stand with you" (G. Bush, 2005).

American hegemony has manipulated two concepts that of democracy and veiling through which it oppresses Arabs and Muslims in the Middle East. It has employed double standards in the way it represents these two concepts and uses them as tools to oppress and justify its war on terror. US hegemony has culturally and mentally colonized several Middle Eastern countries through its claim of spreading democracy and defending freedoms. This paper reveals the various ways America's double standards are manifested in its spread of democracy throughout the region. It also exposes hegemony's manipulation of values, ideologies, and meanings to reassert the necessity of an American presence in the Middle East. The aim is to provide insight into US double standards in the way it conducts itself on its own land and what it is willing to do on foreign land.

This paper shows the contrast between what is stated in the hegemonic project through various US presidential addresses and US rhetoric of democracy as opposed to its practices in the Middle East. A survey of the literature written about America's foreign policies and hegemonic rhetoric indicates that the Bush administration used the September 11 attack as a justification for its foreign policies aimed at world domination in the name of "protecting" Americans from further terrorist attacks (Coon, 2008). One political commentator wrote that this battle on global terrorism is a big failure that lost international support and is viewed as "a cloak for American designs on empire and oil" rather than a process of democratization or terror elimination (Nossel, 2004, p. 34). Research by Pei and Kasperproved that exporting democracy to other nations the "Bush" way just cannot work. In their research, they found that the US has attempted around seventeen efforts to build democracies in foreign nations since 1900, but only four created democracies remained for at least ten years (as cited in Eland, 2008, p. 92). These forms of democracies naturally fail because they are not built by locals and have not been modifiedto fit the native culture it was meant for and so when a westernized democracy is imposed, it generates anger and resistance and sometimes acts of terrorism. Eland (2008), author of The Empire Has No Clothes: US Foreign Policy Exposed, argued that US "nation building" which actually translates into "meddling in other nation's conflicts and civil wars" can result in terrorism as it is in the cases of Afghanistan and Iraq (p. 92). While US 
hegemonic rhetoric frequently referred to this process of nation building and spreading democracy as a positive motive for invading Iraq, the reality on the ground shows that American and British troops were not "greeted with 'the flowers and sweets' George Bush had been told to expect by the Iraqi exiles who did so much to encourage the invasion" (Dodge, 2010, p. 1269). Resistance movements were actually formed to get rid of the American presence and many American soldiers were rather attacked than welcomed. This contradiction between US rhetoric and the physical reality we live in upset many reporters such as Kessler and Wright (2005) who asserted that former president Bush's rhetoric of freedom and democratization is "at odds with the administration's increasingly close relations with repressive governments in every corner of the world." They saw the growing gap between the US rhetoric and its foreign policy as America's relations with nondemocratic regimes were strengthening during the war on terrorism.

This paper acknowledges the failure of the democratization and nation building attempts discussed in previous studies and goes even further in its argument to consider such a claim within US rhetoric under the framework of hegemony. It also draws a link between the US rhetoric of democracy and its manipulation of the Islamic practice of veiling and certain feminists to advance its own interests in the region. In my argument, I draw on Williams' (1977) definition of hegemony, which was inspired by the Italian activist Antonio Gramsci (1995), to examine US double standards in its rhetoric of democracy and representation of veiling. The issues of democracy and Islamic veiling will be addressed in US government speeches and the hegemonic discourse utilized to ensure American interests are protected in nations such as Afghanistan, Egypt, and Iraq.

Drawing on Gramsci's (1995) theory of hegemony, Williams (1977) argued that "Hegemony" is a concept that includes and goes beyond the two powerful concepts of "culture" as a "whole social process", "in which men define and shape their whole lives;" and that of "ideology," in which "a system of meanings and values is the expression or projection of a particular class interest" (p. 108). Williams (1977) asserted that hegemony goes beyond culture "in its insistence on relating the 'whole social process' to specific distributions of power and influence" (p. 108). That is, hegemony is a system that controls the distribution of power and influence and maintains it within the ruling class which ultimately designs a system of beliefs, a set of ideologies and values, and a certain partial outlook on critical socio-economic and political conditions through which people's lives are controlled and subordinate groups are dominated. It can be described as "the lived dominance and subordination of particular classes" (Williams, 1977, p. 110). In Williams' (1977) critique of hegemony, he concluded:

Hegemony is then not only the articulate upper level of 'ideology', nor are its forms of control only those ordinarily seen as 'manipulation' or 'indoctrination'. It is a whole body of practices and expectations, over the whole of living: our senses and assignments of energy, our shaping perception of ourselves and our world. It is a lived system of meanings and values- constitutive and constituting - which as they are experienced as practices appear as reciprocally confirming. It thus constitutes a sense of reality for most people in the society, a sense of absolute. (p. 110).

This definition shows that hegemony goes far beyond ideology, indoctrination, coercion and power and can be seen as constituting them altogether at once. Hegemony can be viewed as a system of power that is maintained by constantly updating methods of domination, setting and reinforcing certain ideologies, values, meanings, and practices through which people's lives are shaped and defined. Hegemony, as such, can be very oppressive, yet subtle in the dissemination of values and meanings to sustain its power.

In shaping perceptions of the Arab and Muslim world to impose democratic values on it and, ironically, control the region, US hegemonic forces take on the task of constructing an extreme and misconstrued image of the Arab world that oppresses its women and turns its men into terrorists. It also convinces the West of the danger the region poses on the world and its need for domination which is a goal disguised under claims of liberation and democracy. It represents some of its people as terrorists while it simultaneously represents others as oppressed citizens practically begging to be liberated by the US and thus creating a noble image of the US who naturally comes to their rescue.

\section{2. "Common Sense" and Democracy}

The US hegemonic discourse and double standards are reinforced in the former President George Bush's inaugural address in 2005 in which he misled people with his representation of "common sense." He emphasized that liberty in other lands is crucial to the survival of liberty in the U.S. although the government had supported many dictatorships in the region like Egypt and Iraq and even strengthened them for many years.

We are led, by events and common sense, to one conclusion: The survival of liberty in our land increasingly depends on the success of liberty in other lands. The best hope for peace in our world is the expansion of freedom in all the world. (G. Bush, 2005). 
The U.S. rhetoric as such has presented the spread of democracy, especially post $9 / 11$, as the only solution and single commonsensical action to take in the Middle East as it has been made a condition for "the survival of liberty" in the U.S.In this speech, the issues of common sense and freedom need to be addressed from a hegemonic perspective on the one hand, and what they mean to the world, on the other hand. The notion of "common sense" is problematic because what constitutes common sense is debatable as it can constantly be altered in people's consciousness according to time, circumstances, and geopolitics. It is not fixed but is always fluid and interchangeable which makes it and the general public susceptible to manipulation by the ruling class. Whencommon sense is being appropriated and determined for the masses at any given moment in history, as we see in this speech, intellectual constraining is exercised and people are denied opportunities to explore any alternative world views, thus denying them any moments of critical thought or political illumination. Accordingly, hegemonic forces impose their views and ideologies on the public by presenting them as "common sense" which is what Bush did. In this context,it is useful to refer to St. Lawrence University website that states, "The common sense of hegemony suffocates questions, denies challenges, [and] prevents alternative answers," making it a powerful tool in the hands of power to subdue subordinates. That is, once certain perceptions are labelled as "common sense," the public is inclined and feels obligated to submit to them because hegemony had already blocked any alternative world views and created an atmosphere of fear and blind submission in which certain beliefs are accepted and even imposed while others are not, and dissident voices are silenced and accused of being unpatriotic or "un- American." These constructed circumstances are significant to the hegemonic project because they naturally prepare it to impose what the Arab- American writer, Salaita (2005), calls an "imperative patriotism" (p. 154).

Imperative patriotism assumes (or demands) that dissent in matters of governance and foreign affairs is unpatriotic and therefore un-savory. It is drawn from a longstanding sensibility that nonconformity to whatever at the time is considered to be "the national interest" is unpatriotic. (p. 154).

Typically, most average Americans care more about following the law and accepting what the government considers "the national interest" and "common sense" without questioning it than being nonconformists who doubt their own government and maybe challenge the system. That said, many Americans make sure to stress their patriotism and loyalty to the US out of fear and intimidation and so as not to be condemned by society. Having established this understanding of an imperative patriotism and common sense, the goal behind using common sense is achieved as it has served its purpose in "[suffocating] questions, [denying] challenges, [and preventing] alternative answers." It only becomes reasonable under these circumstances for the public to readily accept that the only way to protect American freedom and democracy is to "[expand] freedom in all the world," as former president Bush suggested.

There is no doubt that the spread of democracy and the expansion of freedom in the world is a noble cause as such values are important to citizens all over the world. It is sound for all people across cultures and nations not to want to live incarcerated, imprisoned, or restricted and to appreciate the value of freedom. However, the danger lies in the way the US transfers its democracy and freedom to the rest of the world and the Middle East, in particular. The idea to create a new world order by "spreading democracy" is not merely "quixotic- it is dangerous," wroteHobsbawm (2005) in his discussion of the dangers of exporting democracy in The Guardian. Hobsbawm (2005) rejected the idea that democracy can be exported or imposed on states in order to remake the world. He believed that the $20^{\text {th }}$ century had already demonstrated that states cannot bring about social change by "transferring institutions across borders." Hobsbawm (2005) commented on Bush's second inaugural address in which he does not find him putting much stress on Iraq, Afghanistan, or the war on terror but still believes that:

The rhetoric implies that democracy is applicable in a standardised (western) form, that it can succeed everywhere, that it can remedy today's transnational dilemmas, and that it can bring peace, rather than sow disorder. It cannot.

America's double standards are evident in its application of democracy on US soil as opposed to its non-democratic practices in the Middle East. In fact, the US determines whether a democracy is needed in certain regions or not and we have seen this attempt to spread a standardized western democracy and liberate women in Afghanistan fail. This notion of transferring democracy and bringing about world order is nothing but another form of imperialist domination over regions like Afghanistan and Iraq. The US double standards are manifested in this claim to spread democracy because this attempt will come in a rather westernized form ignoring indigenous traditions, destroying cultures, and frequently replacing its indigenous languages making English the official language of the country as the British empire did in the past. To impose a western democracy on a non-western country does not make it a noble cause, on the contrary, it is another type of oppression and silencing of its natives. 


\section{Hegemony and Double Standards}

\subsection{Afghanistan}

The US had originally used 9/11, the war on terror, and the rhetoric of democracy to legitimize its invasion of Afghanistan and Iraq. As the US constructs itself as a hegemonic power, it has to constantly alter and renew its methods and itself to maintain its dominance over other regions. This renewal of itself is a condition for hegemony to succeed (Williams, 1977, p. 112). According to Williams (1977), "[Hegemony] does not just passively exist as a form of dominance. It has continually to be renewed, recreated, defended, and modified. It is also continually resisted, limited, altered, challenged by pressures not at all its own" (p. 112). The US successfully accomplishes this and maintains its power by adopting the rhetoric of the spread of democracy and liberation of Muslim women to justify its military intervention in Afghanistan. It has deceived the world and the American people by portraying its invasion of Afghanistan as part of a humanitarian interventionism. The US and its skewed standards become apparent when it simultaneously assigned itself as a custodian of human rights and prevented democracies from being established in the Middle East through its support of existing dictatorships throughout the region, Egypt being a major example. Zunes (2010), international studies expert, examined the relationship between the US and Egypt pointing out that "Although the State Department acknowledges that the regime suppresses freedom of the press, association, and religion, the U.S. government under both Republican and Democratic administrations -annually rewards Mubarak with billions of dollars worth of military and economic assistance." In this case, the rhetoric of "spreading democracy" is not consistent with US government actions in the region.

In reality, any other form of democracy different from that prescribed by the US is automatically rejected on the basis of the Eurocentric and Orientalist binary of "us" and "them" and the assumption that the 'other' is incapable of being democratic, and so such a western ideal and cherished value ought to be imported from the US and the First World. There is a double standard in the US appointing itself a protector of human rights and distributor of freedoms and democracies as it cannot really afford to support a real democracy in Islamic states. Political scientist Alvi-Aziz (2008) indicated that:

Immediately after the fall of the Taliban regime, the priority in "reconstruction" efforts was makeup, hair salons, and beauty, supplied by top Western cosmetic multinational corporations like Revlon, L'Oreal, Clairol, and Vogue in an effort to implant free market capitalism in post-Taliban Afghanistan. . . They have . . introduced Western hyper-capitalism and consumption into impoverished Afghan society. (p. 171-172).

These "reconstruction" efforts are never reported to the American public while the rhetoric of freedom and democracy continues to prevail. It seems plans to advance a true democracy that carries out fair elections and achieves economic independence never materialize. The US has not only crippled the progress of Afghanistan, but has also obstructed any chances for a democratically elected government to take control. As "American support for Muslim democracies would require the free expression of dissonant voices; otherwise they would be labeled illegitimate" (Zambelis, 2005, p. 89). The US cannot run the risk of having governments that may be "Islamists, nationalists, or openly hostile to the United States and its allies?" (Zambelis, 2005, p. 89). Having an electoral democracy would most likely lead to changes and a transformation undesired by hegemonic forces. Washington cannot really back up its rhetoric of freedom and democracy in the region with action because if it does, it may have to deal with a fairly elected government that is possibly anti- American or wishes to strengthen its relations with China, Europe, and Russia rather than the US (Zambelis, 2005, p. 94).

The United States has traditionally been reluctant to press its Arab and Muslim allies on the issues of human rights and political reform based on the assumption that any democratic opening would threaten their pro-U.S. orientation or lead to their replacement by something far worse. (Zambelis, 2005, p. 94).

Given this context of a possible Muslim democracy that may pose a threat to US economic interests, it becomes imperative for Washington to deepen the divide between "us" and "them" through its rhetoric to justify its war on Afghanistan. Former President Bush manufactures an enemy that threatens the existence and survival of all kinds of freedoms that the whole world ought to stand up to and make a final decision, whether to be with "us" or the terrorists. This can be illustrated through his address to a joint session of Congress in 2001:

On September 11th, enemies of freedom committed an act of war against our country . . Americans are asking, why do they hate us? They hate what we see right here in this chamber - a democratically elected government. Their leaders are self-appointed. They hate our freedoms-our freedom of religion, our freedom of speech, our freedom to vote and assemble and disagree with each other . . Every nation . . . now has a decision to make. Either you are with us, or you are with the terrorists. (G. Bush, 2001). 
The attack on September 11 here is attributed to Muslims' hatred of American freedoms, and the former president portrays all kinds of freedoms being under the threat of Islamic terrorism and "enemies of freedom." When the situation is represented that way, like everything the U.S. stands for is being attacked, people will certainly choose to be with "us" and not with the terrorists; that becomes the only commonsensical option available under the circumstances. He goes on to criticize the "self- appointed" leaders in the region in front of the American public while he supports them behind the scenes as was the case with Egypt, Iraq, and Afghanistan. Nevertheless, he sets the stage to fight the "enemies of freedom" and takes on the role of protector of civil liberties.

\subsection{Egypt}

It is ironic that the "protector of civil liberties" who claims to support "the growth of democratic movements," and "expansion of freedom in all the world," has authorized and committed many violations in Egypt in cooperation with its oppressive government.Dickinson (2011) wrote about the many repressions of Egypt's 30-year-president in her article "The Anatomy of Hosni Mubarak's Dictatorship":

Torture is widely used to extract confessions to all variety of crimes. Most infamous are the instances of "renditions," in which Egyptian authorities have interrogated alleged terrorists and enemy combatants captured by U.S. forces using methods that would be illegal on American soil. Mubarak's newly appointed vice president, Omar Suleiman, a former chief of the intelligence service, oversaw dozens of such renditions, according to Pulitzer Prize-winning journalist Ron Suskind. "When [the United States] wanted someone to be tortured, we'd send him to Egypt to have them tortured," Suskind recently told ABC News.

This only shows America's double standards in its practice of human rights laws. It permits and even expects other countries like Egypt to commit violations it does not allow on its own soil. It has manipulated Egypt to perform acts of cruelty on its behalf against alleged terrorists while it appears noble on the international front whose main concern appears to be justice and human rights. In fact, early into Barack Obama's presidency, he confirmed his continued unconditional aid to Egypt and Secretary of State Clinton declared that "there would be no human rights "conditionality" in the close relationship between the United States and Egypt, regarding foreign aid or anything else," explained Zunes (2010). The fact that the US has continued its foreign aid to Egypt for 30 years in spite of its violations leads us to an awareness of the common interests US and Egypt share. Egypt tortures America's enemies on its own land to protect America's reputation as a democratic and civil nation and in return it gets paid for such an assistance and Mubarak's dictatorship is protected by the US.

\subsection{Iraq}

The United States obviously overlooks the violations of human rights and the injustices that take place in the Middle East, and even supports its undemocratic practices, because it is these violations that actually protect American interests in the region. The US continued to support Hosni Mubarak for around 30 years although he was a dictator just as it had previously supported Saddam Hussein who also oppressed his people until the US decided to end his regime. The US had allowed both regimes to practice atrocities in their nations and against innocent civilians for a long time without imposing on them any forms of democracy. Its recent mission to spread democracy did not apply to Egypt, and Iraq was not a target prior to 9/11 but later on, in the global war on terror, ending its regime became a goal the US sought to accomplish.

The US hegemonic project needs to succeed in its imperialist endeavours and so has to use the rhetoric of democracy to justify its conduct to the international community so as not to provoke much resistance domestically or internationally even if it involves sending out contradictory messages. That is, it has indirectly silenced its people with an "imperative patriotism" and misguided the world with its noble mission and war on terror creating no alternatives for the average public. In the 2005 inaugural Address, former President Bush stated:

[I] is the policy of the United States to seek and support the growth of democratic movements and institutions in every nation and culture, with the ultimate goal of ending tyranny in our world.

Unfortunately, in the case of Egypt and many other countries in the Middle East the goal to end tyranny in the world is not a priority on the American political agenda. Surprisingly, this goal is presented when the US decided that Iraq had nuclear weapons, which has been proven false, and is dangerous to the world. Sadam Hussein's tyranny became a top priority for the US government and a war was launched killing thousands of innocent people in the name of justice and freedom from the Arab tyrant only to be replaced by US tyranny and injustice. US double standards become clear when speeches about freedom and democracy are constantly delivered on its own land while the killing continues on other lands like Iraq's and Afghanistan's. 
Obviously, there is a contradiction between US practices in Iraq and what is being preached in government speeches. Let us contrast the language used in former President Bush's speech on the war on terrorism with what has actually happened on Iraqi grounds:

As we train Iraqis to take more responsibility in the battle with the terrorists, we're also helping them build a democracy that is worthy of their sacrifice... And in just over two and a half years, the Iraqi people have made incredible progress on the road to lasting freedom. Iraqis have gone from living under the boot of a brutal tyrant to liberation, free elections and a democratic constitution, and in 15 days they will go to the polls to elect a fully constitutional government that will lead them for the next four years. (G. Bush, 2005).

A few rhetorical questions arise when analyzing this speech: If Iraq had great power and nuclear weapons, and harbored terrorism as the US had claimed, would it need any external assistance for the training of its military forces? Wouldn't a powerful country as such be self- sufficient and able to defend itself with its own military without waiting for foreign assistance? Nevertheless, the portrayal of Iraq as needing help to fight terrorism and build a democracy is crucial to the success of the hegemonic project and reinforcement of its imperialist plans to expand and control oil resources in the region. Furthermore, in light of a prevailing hegemonic project, using words like "democracy," "incredible progress," "lasting freedom" will help the US gain popularity in the world and even contribute to its growing respect and trust from the international community for its admirable mission to fight terrorism and achieve world peace. Once it has justified its invasion and war on Iraq under these titles, it can proceed with its hidden agenda without being faced with skepticism. Bush's words and vision seem very promising to the Iraqi people, but the reality on the ground reflects an entirely different existence and future for them. In an examination of the deteriorating conditions in Iraq under US occupation, Zangana (2004) declared that:

Lack of security and fear of kidnapping make Iraqi women prisoners in their own homes. They witness the looting of their country by Halliburton, Bechtel, US NGOs, missionaries, mercenaries and local subcontractors, while they are denied clean water and electricity. In the land of oil, they have to queue five hours a day to get kerosene or petrol. Acute malnutrition has doubled among children. Unemployment at $70 \%$ is exacerbating poverty, prostitution, backstreet abortion and honour killing. Corruption and nepotism are rampant in the interim government... The killing of academics, journalists and scientists has not spared women: Liqa Abdul Razaq, a newsreader at al-Sharqiyya TV, was shot with her two-month-old baby. Layla al-Saad, dean of law at Mosul University was slaughtered in her house.

Sadly, Iraq has witnessed a severe decline in all aspects of life since the US invasion. It is tragic that Iraqis have to suffer on their own land and experience humiliation and extreme injustice merely because their nation and its resources are paramount to America's imperialist project. This path filled with misery and oppression can in no way lead to a "lasting freedom" or a democratic constitution as Bush has claimed.

\section{Liberating Women and the Veil}

The violation of human rights and the current situation in Iraq, and Afghanistan, has not only resulted from the hegemonic project, its rhetoric of democracy and war on terror, but has been also coupled with the myth of an urgent need to liberate Muslim women. That is, various speeches about democracy and freedom in Iraq and Afghanistan also focused on the liberation of Muslim women and the need to rescue them from Islamic oppression and veiling.

In a radio address on November 17, 2001, Former First Lady, Laura Bush, stressed the need for military action to liberate Muslim women of Afghanistan and claimed that the struggle against terrorism is also a fight for "the rights and dignity of women." The rhetoric she uses makes the condition of Afghani women an issue that concerns all humanity which in turn will make terrorism a human dilemma that calls for the unity of people worldwide to end it and the Taliban regime. In doing this, Afghan women are used as part of the rhetoric of democracy and war on terror only to get the world's moral and military support for U.S. interference in the Middle East and control of the region.

The plight of women and children in Afghanistan is a matter of deliberate human cruelty, carried out by those who seek to intimidate and control. Civilized people throughout the world are speaking out in horror -- not only because our hearts break for the women and children in Afghanistan, but also because in Afghanistan we see the world the terrorists would like to impose on the rest of us. (L. Bush, 2001)

This statement creates in people's minds a false perception of the oppressive world terrorists want to impose on women and the Western world to evoke fear and gain approval for U.S. violence in the Middle East. This has been a successful strategy followed by hegemony as it controls "our senses and assignments of energy, our shaping perception of ourselves and our world" (Williams, 1977, p. 110). In addition, it has been important for 
the US to represent itself to the world as the savior and protector of women's rights. While it shapes this perception of itself, the US also imposes on the world perceptions of the Muslim and veiled woman as an average Third World woman who is "sexually constrained," and "ignorant, poor, uneducated, tradition-bound, domestic, family-oriented, victimized... this... is in contrast to the (implicit) self-representation of Western women as educated, as modern, as having control over their own bodies and sexualities and the freedom to make their own decisions" (Mohanty, 2003, p. 22).

The US utilizes this feminist rhetoric to achieve its imperialist goals in the Middle East. It represents Muslim and veiled women in a negative light to establish a need for US intervention to alleviate their situation. In reality the need to "liberate" Muslim women in Iraq does not exist because they did not suffer from Islamic oppression, inequality, or injustice prior to the US invasion. In fact, they lived under a secular regime and actually enjoyed many of their rights as free independent women under Saddam's ruling. Hassan (2005) described the situation of women in Iraq before its occupation:

Prior to the 1991 U.S. war and the 13 years of the genocidal sanctions, Iraqi women enjoyed unquestionable quality rights to education and health. Iraqi women had the most progressive human rights in the region and Iraqi women were the first Arab women to hold high positions in academia, law, medicine and government. Before the U.S. invasion and occupation of Iraq, Iraqi women made up 40 per cent of the public-sector work force. Men and women received equal pay for work, education, and health care were free at all levels. In the 1980s, a government program to eradicate illiteracy among Iraqi women was exceedingly successful, and women have traditionally enjoyed freedoms not found in other Arab and Muslim countries. (p. 2).

It has always been known to Middle Eastern peoples that Iraq was one of the most liberal and progressive countries in the region, and so it is no surprise that women played a great role in the advancement of Iraq and enjoyed equality with men. Nevertheless, the hegemonic project, its double standards, and economic interests dictate that the US ignores the atrocities that are committed against Muslim women in other Middle Eastern countries because it cannot afford to export its "standardized democracy" and send its troops across borders to "liberate" these women. The Iraqi situation, however, presents the US with resources and oil it has to gain control over, as a hegemonic power, to advance its own economic development, thus, justifying its fraudulent concern for Iraqi women. Hassan (2005) asserted that Iraqi women were free to travel around the country as they wished and wear whatever they wanted, for the 1970 Iraqi constitution gave Iraqi women "equity and liberty unmatched in the Muslim World" (p. 10). These prosperous conditions of Iraqi women that are "unmatched" in the Muslim world do not need to be altered, nor do the women need to be liberated as veiling was never imposed on them in the first place. This reality hidden from many Americans reflects hegemony's double standards and manipulation of Islamic veiling to serve its imperialist endeavors in the region.

This focus on the veil, Muslim feminists explain, is typical of colonial rulers as it did not grow out of the colonialists' concern for women, their equality, or freedom. Rather it was just part of the colonial endeavor and a way to degrade the colonized subjects, justifying their control over their lands (Haddad, 2007, p. 257). Ahmed (1992), an Islamic feminist, stated that male imperialists known for their "intransigent opposition to feminism" in their own societies led "the attack abroad against the 'degradation' of women in Muslim societies and were the foremost champions of unveiling. The custom of veiling and the position of women in Muslim societies became, in their rhetoric, the proof of the inferiority of Islam and the justification of their efforts to undermine Muslim religion and society" (p. 160-1). America in the present has used the veil to further its imperial interests in the Middle East as British colonialists did before.

\subsection{Veiling after $9 / 11$}

US hegemony's double standards are evident when it simultaneously advocates plurality, religious tolerance, and freedom of choice and allows the condemnation and harassment of Muslim veiled women to continue, especially post $9 / 11$, in mainstream society simply because they represent the unwanted "Arab other" and a religion the US rejects and misinterprets as violent and backward. Because of the power hegemony has over people's consciousness and perceptions of the world, Muslim women are continuously faced with challenges inside the US and in the Middle East as well. On the one hand, they constantly struggle with people's colonialist perception and stereotypical images of them on US soil. On the other hand, they are also forced to deal with the spread of the hegemonic rhetoric of Muslim women's liberation and oppression across the Middle Eastern region and the whole world. Many have been mistreated in their own countries due to this unjust rhetoric that has led many Arabs and non- Arabs, Muslims and non-Muslims alike, to despise the veil and view it as emblematic of backwardness, subordination, and sexual oppression, thus preventing them from advancing in their own homelands. In fact, during the war on Afghanistan, U.S. media had been continuously circulating images of 
Afghan women in burqas desperately needing rescue and representing them as symbols of oppression (Qutami, 2011, p. 174). The irony, however, and to the West's surprise, many Afghan women chose to wear the burqas even after they were "liberated" from the Taliban. British journalist, George (2001) reported that:

Western journalists and aid workers who thought that piles of burqas would be burned in the street as the Taleban (sic) made a quick getaway are in shock. They are incredulous that what has been perceived as the arch symbol of Taliban rule is worn even when the regime is long gone.

The fact that Afghan women continued to put on their burqas and did not burn them even after they got rid of the Taliban only shows that there is a misconception that connects the veil or burqa to the Taliban and its oppression of women that ignores the reality that millions of women all over the world have taken on the Islamic veil just like any other religious practice exercised by Muslims long before the Taliban ever existed (Qutami, 2011, p. 175).

There is a contradiction in hegemony's portrayal of the practice of veiling as both: a sign of subordination and oppression within a Middle Eastern context and, at the same time, regarding it a serious threat to the homogeneity of American society thereby attaching a certain power to it (Qutami, 2011, p. 169). This inconsistency is hardly recognized by the public as the opposing representations of the veil are never used side by side in US rhetoric. According to the political theorist Sheth (2006):

Significant cultural difference-understood as a profound and defiant challenge to a certain kind of cultural homogeneity - is threatening. This latter heterogeneity, as embodied by Muslims today, represents a challenge to the values of a Western liberal- secular political order and to "reasonable" and law-abiding members of the polity. (p. 456).

The cultural difference marked by the veil has become the symbol of an unwanted heterogeneity and "foreigness" that is not appreciated or welcomed by the mainstream. The status of the Muslim practice has been raised to "the level of extreme threat" through the great attention, or to be more accurate, the great negative attention it has been given and what it has been misassociated with (Sheth, p. 457). Islamophobia has also contributed to its representation as an increased threat that needs to be "managed, and tamed, or ousted from the polity" (Sheth, p. 457). This contradiction in the representation of veiling is justified as US hegemony needs to present it as a source of oppression to establish a need for its invasion of Muslim countries but at the same time it needs to protect its society from the "foreignness" it represents and its "assumed" threat to American cultural homogeneity.

\subsection{Co-opted Feminists}

The hegemonic project includes many feminists who have been co-opted and represent an imperialist and colonialist mentality in their attempt to "liberate" Muslim women. When these feminists speak on behalf of Third World women, Arab and Muslim in particular, they are actually silencing them. While various strands of Western feminists fight to speak for themselves and represent their own identities, they do not grant Arab/ Muslim women the same right of speech and representation. They speak for them and construct identities based on their personal perceptions of them which in turn silences them. This situation reveals the double standards some feminists have when dealing with Arab/ Muslim women. Many feminists along with hegemonic forces have decided that the Muslim veil is no more than a source of oppression and a way through which men control their women. Having this perception, they are unable to include Arab/ Muslim women in their conversations and battles for women's freedom. Thus, Arab/ Muslim women feel invisible within Western feminist circles. They found themselves "The Most Invisible of the Invisibles," as Arab- American writer and feminist, Kadi (1994) coined the phrase to describe her Arab-American community (p. xix). If Arab feminists, secular and unveiled, feel this way, veiled Muslim women must feel invisible ten times more. Because of the US dominant hegemonic rhetoric on the veil, they are ignored, underestimated, and even silenced by many Western feminists. This occurs when feminists are unable to let go of their colonial and imperialist mentality and its own construction of "the homogenized Muslim female identity."

Hegemony's double standards can be seen when the US empowers and supports many Western feminists to assist it in furthering its oppression of Arab Muslim women. They are represented as First World feminists who are experts on women and their needs. Hinterberger (2007) argued that these colonial feminists act on the presupposition that they have "unmediated knowledge of who 'oppressed people' are and what is in their interests" (p. 75). These certain strands of feminism, under US hegemony, who assume what Hinterberger (2007) calls the "obviousness of oppression" (p. 75) of Arab women have decided that it is in the best interest of Muslim women to give up on the veil because it restricts them and they deserve to be liberated by the West through unveiling and imitating the western lifestyle. In doing so, these colonial feminists have reproduced the 
Orientalist binary of western/ non-western, First World/ Third World, and modern/ backward, and thus, contributed to Arab women's oppression. In this way, they have ruined many feminist efforts that actually aim at creating a paradigm shift and challenging power relations to improve the conditions of men and women around the world.

\section{Conclusion}

This analysis of the hegemonic project, its double standards, and its adoption of some feminists provides an insight into the way any hegemonic force recreates itself and renews its methods to advance its imperialist interests. It seems its contradictoriness is not accidental but rather a continued adaptation of itself to time and geopolitics and an act of modification of its rhetoric and representation of issues depending on how these issues relate to a certain peoples and cultures and the political atmosphere it creates. This is reflected in the way the American people are addressed domestically by hegemonic forces as opposed to US foreign affairs and its practices in the Middle East and the cases of Egypt, Iraq, and Afghanistan are perfect examples of how the US applies itself on foreign lands as part of the hegemonic project. Actually, America's stress on veiling and liberation of women is intriguing as it chose an issue and practice that concerns millions of Muslims in the Middle East thereby magnifying the region's "supposed" need for American assistance. As hegemony continues to alter its ways and methods of handling the public and what constitutes common sense, it makes us wonder about the sign or issue that will eventually replace that of veiling and women's liberation only to be manipulated by future hegemonic projects and made the focus of their rhetoric and discourse.

\section{References}

Ahmed, L. (1992). Women and gender in Islam: Historical roots of a modern debate. NewHaven: Yale University Press.

Alvi-Aziz, H. (2008). A progress report on women's education in post- Taliban Afghanistan. International Journal of Lifelong Education, 27, 169- 178. http://dx.doi.org/10.1080/02601370801936333

Bush, G. (2001, Sept. 21). Transcript of president Bush's address. CNNU.S. Retrieved from http://articles.cnn.com/2001-09-20/us/gen.bush.transcript_1_joint-session-national-anthem-citizens?_s=PM: US

Bush, G. (2005, Jan. 20). President Bush's second inaugural address. NPR. Retrieved from http://www.ohio.edu/people/hartleyg/docs/Bush\%27s\%202nd\%20Inaugural\%20Address.pdf

Bush, L. (2001, Nov. 17). Radio address. The American presidency project. Retrieved from http://www.presidency.ucsb.edu/ws/index.php?pid=24992

Coon, C. (2008). Toward a humanist foreign policy. The Humanist. Retrieved from http://www.thehumanist.org/humanist/Coon2-08.html

Dickinson, E. (2011, Feb. 4). The anatomy of Hosni Mubarak's dictatorship.Foreign Policy. Retrieved from http://www.foreignpolicy.com/articles/2011/02/04/anatomy_of_a_dictatorship_hosni_mubarak

Dodge, T. (2010). The ideological roots of failure: The application of kinetic neo-liberalism to Iraq. International Affairs, 86(6), 1269-1286. http://dx.doi.org/10.1111/j.1468-2346.2010.00942.x

Eland, I. (2008). Back to the future: Rediscovering America's foreign policy traditions. Mediterranean Quarterly, 19, 88- 98. http://dx.doi.org/10.1215/10474552-2008-015

George, M. (2001, Nov. 23). Afghan women enjoy their freedom. BBC News. Retrieved from http://news.bbc.co.uk/2/hi/south_asia/1672488.stm

Gramsci, A. (1995). Further selections from the prison notebooks. (D. Boothman, Trans.). London: Lawrence and Wishart. (Original work published 1971).

Haddad, Y. Y. (2007). The post-9/11 hijab as icon. Sociology of Religion, 68(3), $253-267$. http://dx.doi.org/10.1093/socrel/68.3.253

Hassan, G. (2005, May 6). Iraqi women under occupation.Global Research: Center for Research on Globalization. Retrieved from http://www.globalresearch.ca/iraqi-women-under-us-occupation/158

Kessler, G., \& Wright, R. (2005, Jan 21). Bush's words on liberty don't mesh with policies: U.S. maintains close ties with repressive nations. Washington Post. Retrieved from http://www.washingtonpost.com/wp-dyn/articles/A24581-2005Jan20.html

$\begin{array}{lllll}\text { St. } & \text { Lawrence } & \text { Glossary. } & \text { Retrieved }\end{array}$ 
http://it.stlawu.edu/ global/glossary/bighegemony.subculture.1b.html

Hinterberger, A. (2007). Feminism and the politics of representation: Towards a critical and ethical encounter with 'others. Journal of International Women's Studies, 8, 74-83. Retrieved from http://www.bridgew.edu/soas/jiws/feb07/hinterberger.pdf

Hobsbawm, E. (2005, Jan. 22). The dangers of exporting democracy. The Guardian. Retrieved from http://www.guardian.co.uk/world/2005/jan/22/usa.comment

Kadi, J. (1994). Introduction. In J. Kadi (Ed.), Food for our grandmothers: Writings by Arab American and Arab-Canadian feminists (pp. 13-20). Boston: South End Press.

Mohanty, C. (2003). Feminism without borders: Decolonizing theory, practicing solidarity. Durham: Duke University Press.

Nossel, S. (2004) Foreign policy: How America can get its groove back. Dissent. Retrieved from http://207.97.238.133/article/?article=308

Qutami, M. (2011).The veil (de)contextualized and nations "democratized": Unsettling war, visibilities, and U.S. hegemony. Works \& Days: Invisible Battlegrounds: Feminist Resistance in the Global Age of War and Imperialism, 29, 159-178.

Salaita, S. (2005). Ethnic identity and imperative patriotism: Arab Americans before and after 9/11. College Literature, 32, 146-168. http://dx.doi.org/10.1353/lit.2005.0033

Sheth, F. (2006). Unruly Muslim women and threats to liberal culture. Peace Review: A Journal of Social Justice, 18, 455-463. http://dx.doi.org/10.1080/10402650601030328

Williams, R. (1977). Marxism and literature. Oxford: Oxford University Press.

Zambelis, C. (2005). The strategic implications of political liberalization and democratization in the Middle East. Parameters, 35, 87-102.

Zangana, H. (2004, Dec. 22). Quiet, or I'll call democracy. The Guardian. Retrieved from $\mathrm{http} / / / \mathrm{www}$. guardian.co.uk/world/2004/dec/22/iraq.gender

Zunes, S. (2010, Dec. 7). Fraudulent Egyptian election. Foreign Policy in Focus. Retrieved from http://www.fpif.org/articles/fraudulent_egyptian_election 